811.163.41'366

811.163.41'373.611

https://doi.org/10.18485/sj.2019.24.1.31

САНА Ж. ЋУРОВИЋ

Универзитет у Крагујевцу

Филолошко-уметнички факултет
Оригинални научни рад

Примљен: 11. 09. 2018.

Прихваћен: 15. 01. 2019.

\title{
ПРОБЛЕМИ У МОРФЕМСКИМ АНАЛИЗАМА РЕЧИ У СРПСКОМ ЈЕЗИКУ**
}

Предмет рада јесу конкретни примери морфемских анализа речи где се јављају проблеми у вези са одређењем типа морфема и класификацијом морфема у погледу поделе на граматичке и творбене морфеме. Испреплетаност и повезаност морфемске и творбене анализе често доводи до двојаких решења па је циљ рада предлог за критеријалну и доследну морфемску анализу као и јасно одвајање морфемске, морфолошке и творбене анализе као три основне анализе у оквиру морфологије и творбе речи.

Кључне речи: морфологија, морфема, морфемска анализа, српски језик

1. О морфемама се говори у више језичких дисциплина - морфонологији, морфологији, творби речи, лексикологији. У србистици се о морфемама ${ }^{1}$ разматра у морфологији и творби речи, које су уско повезане лингвистичке дисциплине. Три основна типа анализе јесу морфемска, морфолошка и творбена

*sdjurovic74@gmail.com

** Рад је урађен у оквиру пројекта Динамика структура савременог српског језика (бр. 178014) који финансира Министарство просвете, науке и технолошког развоја Републике Србије.

${ }^{1}$ Најчешћа дефиниција морфеме је да је то најмања језичка јединица која има значење, односно одређену функцију у реченици. „Са морфолошког и творбеног становишта, реч се састоји од једне или од више морфема, а морфема је најмања језичка јединица која је носилац или значења или граматичке службе у реченици” (Станојчић/Поповић 2008: 70). „Морфема је најмањи део (сегмент) речи који има неко значење или функцију” (Мразовић/Вукадиновић 2009: 20). „Морфема је најмања језичка јединица која има значење” (Пипер/Клајн 2013: 48). 
анализа. Предмет овог рада биће само морфемска анализа и неки проблеми у вези са одређењем типова морфема. Циљ рада јесте указивање на значај ових питања у морфологији српског језика, указивање на јасно постављене критеријуме у морфемској анализи, али и на недоследна тумачења у литератури која отежавају анализу. Морфолошка и творбена анализа биће на конкретним примерима супротстављене морфемској анализи како би се јасно издвојила три различита типа анализе 2 .

2. Морфемска анализа речи подразумева уочавање свих морфема од којих се она састоји. „Морфемску структуру речи чине различите комбинације морфема. Наставак је морфема која има граматичко значење и налази се на крају речи." (Пипер/Клајн 2013: 48). Речи могу бити једноморфемске, двоморфемске и вишеморфемске. Морфеме се деле на везане и слободне и на корене и афиксе. Афикси се деле на граматичке и творбене. На пример у речи кућедомаћин издвајамо следеће морфеме: кућ-е-дом-аћ-ин-ø (два корена: кући дом-, спојни вокал (интерфикс) -e-, суфиксе - $а ћ$ и -ин и нулти наставак). У примеру градоначелник издвајамо следеће морфеме: град-о-на-чел-н-ик-ø (два корена: град- и чел-, спојни вокал (интерфикс) -о-, суфиксе -н и -ик и нулти наставак). Наведени примери су неспорни и морфеме се јасно могу одредити. Ипак, има и оних примера где су неке морфеме са двојаком функцијом или су приступи у морфемској анализи били у литератури недоследни. Управо ће о таквим примерима бити речи у овом раду.

2.1. Морфолошка анализа значи одредити морфолошку (граматичку) основу и наставке. Правило је да код именских речи граматичку основу одређујемо тако што упоредимо облик номинатива и генитива и оно што је исто јесте граматичка основа, а оно што се мења јесте наставак за облик. На пример: Н. кућедомаћин-ø Г. кућедомаћин-а; Н. градоначелник-ø Г. градоначелник-а.

Граматичке основе су кућедомаћин-, градоначелник-, а - $а$ је наставак за облик. Граматичка основа може се одредити и из номинатива или било ког другог падежа, али је сигурније то учинити из генитива пошто у номинативу често имамо окрњене основе, резултате гласовних промена и сл. Тако нпр. Н. сто-ø, Г. стол-а; Н. пас-ø, Г. пс-а; Н. један-ø, Г. једн-ог; Н. добар-ø, Г. добр-ог и сл.

Код глагола урадити морфолошку анализу значи одредити презентску и инфинитивну основу глагола. Често имамо обличко поклапање основа, али презентска и инфинитивна основа никада нису исте, већ се разликују у дужини завршног вокала основе (нпр. код гл. сањати инф. сањ $а$ - : през. сањ $а$-; код. гл. држати инф. држа- : през. држи- итд.).

\footnotetext{
${ }^{2}$ Иако се некада у анализи неке речи формално могу поклапати две анализе, оне никада нису исте и увек постоји неки дистиктивни фактор (прозодија, функција, граматичка/творбена морфема и сл.).
} 
2.2. Творбена анализа значи одредити творбену/е основу/е и афиксе. Резултат творбене анализе јесте одређење творбеног модела на основу ког је нова реч настала. У творбеној анализи најважније је питање критеријума које се користи у анализи па се поред семантичког и формално творбеног критеријума често користи и тзв. последњи чин у творби ${ }^{3}$ који често има оправдања јер логички прати творбени ланац. Тако би творбена анализа именице кућедомаћин била кућ-е-домаћин ('домаћин куће', сложеница) пошто имамо посебне лексеме кућа и домаћин и њиховим спајањем помоћу спојног вокала добијамо нову именицу. Тако и код именице градоначелник (град-о-начелник). У литератури налазимо различите творбене моделе и за поменуте именице, али проблеми у творбеној анализи биће тема посебног рада.

2.3. У литератури се типовима морфема посвећују врло мало простора. Оно што је проблематично јесте често мешање граматичких и творбених морфема. Постоје спорадични случајеви где се једна морфема може тумачити двојако, односно можда би било најбоље говорити о морфемама које су на граници граматичких и творбених.

Много је више творбених него граматичких морфема. Може се рећи да су граматичке морфеме затворена класа и могу се набројати, док су творбене морфеме отворена класа и мање су ограничене.

2.3.1. Граматичке морфеме служе за обележавање различитих облика једне исте речи, имају неку граматичку функцију (да укажу на облик, падеж, граматички број, лице, род и сл.). Граматичке морфеме су предмет морфологије. Поред падежних наставака (где спада и нулта морфема), ту спадају и проширења основе (традиционално називани у србистици инфикси) -ов- (-ев-), -m-, -н-, -с- (нпр. град-ов-и, син-ов-и, дугмет- $а$, имен-а, небес-а), морфеме за творбу одређеног придевског вида (нпр. леп- $u$, вредн- $u$ ) и компаратива (нпр. леп-ши, вредн-ији), префикс нај- за творбу суперлатива (нпр. нај-лепши, нај-вреднији). Код глагола граматичке морфеме су наставци за лице и облик, завршетак презентске и инфинитивне основе ${ }^{4}$, наставак за облик инфинитива -ти (нпр. чит-а-ти; чит-а-мо; чит-а-ју-ћи и сл).

С обзиром на то да се ради о затвореној класи необично је што „[...] ни после више од 150 година постојања дескриптивне граматике савременог српског књижевног језика немамо у њему дефинитивно утврђен ни инвентар једног тако затвореног скупа као што су граматичке морфеме одн. наставци" (Николић 2004: 8).

\footnotetext{
${ }^{3} \mathrm{O}$ овом критеријуму пише Кликовац 2002.

${ }^{4}$ Треба и ту разликовати када је наставак за инфинитивну основу, а када суфикс, а некада је и једно и друго (нпр. пис- $a-m u$ - ту је - $a$ - завршетак инфинитивне основе; jaч- $a$-mu - овде је то и суфикс $-a$ којим је од компаратива придева јак добијен глагол, али је - $a$ - и завршетак инфинитивне основе).
} 
2.3.2. У творбене морфеме спадају творбени афикси (префикс, интерфикс (спојни вокал), суфикс). Творбене морфеме служе за стварање нових речи и њихов инвентар је значајно већи. То је отворена класа и иако постоје листе префикса и суфикса теже их је све набројати јер позајмљивањем речи имамо стални уплив нових творбених форманата из страних језика. Ипак, регистар суфикса и префикса јасно показује значајно већи број творбених у односу на граматичке морфеме па отуда и више пажње која се посвећује творбеним у односу на граматичке морфеме.

3. За морфемску анализу неопходно је јасно одредити начелна правила која се примењују у анализи па се тако могу издвојити следећа:

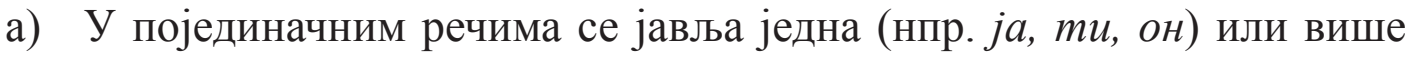
морфема (кућ- $a$, по-врх, чит-а-ти, велик-о-по-сед-ник-б и сл.), али у целом језику има више речи него морфема.

б) Просте и изведене речи имају један корен, а сложенице два или више корена.

в) Сваки суфикс је двоморфемска јединица.

г) У српском језику се зна тачна позиција нултог наставка, док је нулти суфикс недовољно описан ${ }^{5}$. Нулти наставак је граматичка морфема и бележи се код именица мушког и женског рода које се завршавају на сугласник (нпр. јунак-б, љубав-б), код придевских заменица и придева неодређеног вида (добар-б). Нулти суфикс као творбена морфема засигурно се бележи код поствербала и окрњених глаголских основа у другом делу сложенице (нпр. лов-ø, сунц-о-бран-б), али то нису једине позиције нултог суфикса.

д) У морфемској анализи (као и у творбеној) семантички критеријум је обавезан. Мора се знати шта реч значи како бисмо одредили типове морфема. Непознавање лексеме тј. непрозирно значење може нас одвести у погрешна тумачења. ${ }^{6}$

3.1. У највећем броју примера анализа је јасна, али има и доста спорних питања која су најчешће у литератури различито интерпретирана. На мор-

${ }^{5} \mathrm{O}$ нултом наставку и нултом суфиксу писано је у посебном раду који је у штампи.

${ }^{6}$ Колико је семантика важна говори и пример тополовина који је својевремено проф. М. Николић дао студентима друге године ФИЛУМ-а на испиту из Морфологије српског језика и од студената се тражило да ураде морфемску, морфолошку и творбену анализу. Реч није била акцентована. Потпуно неочекивано, велики број студената који очито није размишљао о томе шта реч значи, реч је поделило чисто формално на морфеме овако: *топ-о-лов-ин-а. Тако подељено на морфеме значило би: *лов на топове што се противи свакој логици. Наравно, само они студенти који су укључили семантику одговорили су правилно: топол-ов-ин- $а$ (по моделу: ораховина, храстовина и сл.). Очекивано, они који су погрешили у морфемској анализи погрешили су и у творбеној, па су написали да је реч о сложеници, а ради се о изведеници. 
фемским анализама конкретних примера може се установити који све типови морфема постоје и да границе нису увек јасне. Можда се може говорити и о комбинованом или граничном морфемском статусу поред јасно издвојених граматичких и творбених морфема.

О терминолошким проблемима писано је у раду Ђуровић 2017, па се овом приликом тим питањима нећемо бавити. Ипак, често недоследна и различита употреба термина уноси проблем и ствара мешање нивоа у анализи. Традиционално се у србистици инфикси користе као термин за граматичке морфеме, а интерфикс као термин за творбене морфеме. Ипак, има и других ставова у литератури. ${ }^{7}$ Проблем није само у терминологији него и у схватању шта има статус морфеме. У Граматици Станојчић-Поповић (2008) у инфиксе су убројани и -ов-, -ев-, -н-, -m- и спојни вокали. Измешане су граматичке и творбене морфеме. У србистици се најчешће терминолошки раздвајају инфикси (граматичке морфеме) и интерфикси (творбене морфеме), али и ту има колебања. „Напомињемо да има, и не мало, и друкчијих схватања; има схватања према којима интерфикс уопште није морфема, затим има оних према којима је интерфикс морфема са посебним апстрактним семантичким садржајем, а и оних према којима је без икаквог садржаја, без икакве информације. А ми држимо да је интерфикс граматичка морфема која преноси информацију о слагању самосталних јединица или њихових творбених основа у нову лексичку јединицу" (Гортан Премк 1996: 23). Ово питање и даље је отворено у науци. Тако Маројевић сматра да „компоненте - - -, -m- у облицима племен- $a$, телет- $a$ нису уопште морфеме јер не уносе никакво значење (њихово издвајање противречи основној дефиницији морфеме као најмањег дела речи који има значење. Гласовима $t$ и $m\left({ }^{*} \mathrm{nt}\right)$ у прасловенском језику су биле конституисане одговарајуће сугласничке основе. Данас су они у саставу коренске морфеме /племен/, /телет/, која у номинативу и акузативу једнине има историјски условљен аломорф /племе/, /теле/ испред нултог наставка" (Маројевић 2008: 202). Пошто се у граматикама проширења основе издвајају као посебне морфеме, неопходно је преиспитивање и јасан став науке да ли су проширења основе граматичке морфеме или нису.

За поједине лингвисте морфеме имају место само у дериватологији. Чињеница је да се у већини словенских језика морфематика везује директно за творбу речи (морфематика и словообразование) пошто је много већи инвен-

${ }^{7}$ Према Земској, интерфикси су међуморфемски умеци који у структури речи имају чисту функцију спајања. Она не прихвата идеју о нултим интерфиксима и у интерфиксе убраја сегменте који спајају две основе у сложеницама, затим -ов-, -ев-, -ан. Земска сматра да, ако би се интерфикси ставили у исти ред са суфиксима и префиксима који су значењски сегменти речи, нарушило би се одређење морфеме као најмањег значењског елемента у саставу речи, па би се термином морфема назвале појаве функционално различите. 
тар творбених него граматичких морфема, али ни граматичке морфеме нису небитне и не могу се искључити.

3.2. Једно од спорних питања јесте и да ли је префикс у префиксацији глагола творбена или граматичка морфема (нпр. писати: $y$-писати $)^{8}$. Префиксацијом глагола добијамо нову лексему, али се најчешће мења и вид глагола. Овде је јасно да је префикс првенствено творбена морфема и да је префиксација примарно лексичко-семантички процес, а да је промена гл. вида често пропратна. Може се рећи да овде префикс као морфема има и творбену и граматичку функцију, али је творбена примарна.

О овом питању расправља и Симић и констатује на основу прегледа литературе да префикси код глагола имају улогу и у творби речи и у измени глаголског вида (Симић 2017: 187). То се констатује и у Нормативној граматищи српског језика: „Неки префикси имају чисто граматичка значења, нпр. у глаголу урадити префикс $y$ - има само значење свршеног вида и не мења лексичко значење. Знатно чешће префикси служе за модификовање лексичког значења основе, уп. писати-за-писати - пот-писати - пре-писати и сл." (Пипер/Клајн 2013: 49).

Сама префиксација је веома сложен лексичко-семантички и граматички процес који се може истраживати и на нивоу морфематике. Код глагола се префиксацијом може мењати вид глагола, глаголски род, али и да се добије нова лексема. Ипак, у самој морфемској анализи нема дилеме да ће се префикс издвајати као посебна морфема, само је питање даље анализе која се тиче типа морфеме (граматичка или творбена).

3.3. Бројни примери код глагола отежавају морфемску анализу код примера типа записивати, дописивати, проводацисати, бетонирати и сл. Спорне су морфеме -ив-а-, $-u c-\mathrm{a}^{9}$, -ир-а- где је - $a$ - наставак за инфинитивну основу. Да ли су -ив-, -ис-, -ир- творбене или граматичке морфеме? Да ли су то суфикси или нека врста проширења попут оних која имамо код именица? Јасно је да служе и за творбу нових глагола, али и за имперфективизацију. Пошто се овим морфемама, најчешће, граде секундарно имперфективизирани глаголи који са другим у низу граде чисте видске парњаке могло би се сматрати да се овде ради о граматичким морфемама којима се мења вид глагола, пошто значење остаје исто и не добија се нова лексема (нпр. пис-a-mu : за-пис-а-ти : за-пис-ив-а-ти; хвал-и-ти : по-хвал-и-ти : по-хваль-ив-а-ти и сл.). Ипак, има и оних примера где није овај случај и када добијамо нове лексеме. То зависи и да ли је у творбеној основи глагол или именица (нпр. интервју : интервју-

\footnotetext{
${ }^{8}$ Више о видским парњацима у Ђуровић/Спасојевић 2014.

${ }^{9}$-исати је грчког порекла, али се одомаћио и јавља се и са страним и са домаћим основама. Јавља се и са глаголима у творбеној основи и са именицама (Клајн 2003: 339). Код именица је неспорно суфикс (творбена морфема).
} 
$u c-a-m u)$ те се не може искључиво говорити о творбеној морфеми већ се мора посматрати резултат - да ли се добија нова лексема или се само гради прави видски парњак.

3.4. У литератури налазимо различита тумачења за морфемску анализу глагола. Неки лингвисти не издвајају завршетак презентске/инфинитивне основе као посебну морфему, а други одвајају. Маројевић сматра да код презента глагола имамо наставак -им, -ем, -ам, а не само -м (Маројевић 2008: 202).

Симић констатује да не постоји јединствени критеријум у одређивању границе основе и наставака и да се тако добија неконзистентан систем. Полази од Лескина и његових дефиниција. Лескин дефинише основу као део речи који остаје кад се одстране флексијски наставци (падежни, лични итд.). Симић указује на плурализам морфолошког састава основа које се комбинују са истим наставцима и на примеру глагола дати-дам и уверавати-уверавам констатује да је од важности само чињеница да се код оба глагола испред граматичке морфеме налази вокал - $a$, а да је састав основе мање битан. Статус форманата -ава-, -нy-, -ива-, -ија- је различито третиран у литератури, али Симић сматра да нису само творбени форманти него да имају и граматичку функцију као наставци за инфинитивну основу. Управо ова констатација указује на двојство њиховог морфемског статуса на које је указано у тачки 3.3. „Ми наиме сматрамо да презент није без остатка дељив на основу упоредиву са инфинитивом, и лични наставак. Између основе и личног наставка често посредује вокалски елемент који нема одређеног значења ни морфолошке функције: $m p e c-m u-m p e c-e-м$. То је тематски вокал. Он не припада ни основи ни наставку" (Симић 2005: 90).

У наставку анализе, Симић закључује да је тематски вокал морфолошка категорија као и спојни вокал. То што тематски вокал није морфолошког порекла не издваја га из комплекса творбених елемената (Симић 2005: 94). Оправдано је говорити само о два тематска вокала: $e$ и $u$. Статус -нy- „служи за извођење глаголских речи једних од других по правилу перфективних од имперфективних (дирати-дирнути). Када изгуби ту улогу служи просто за - факултативну - варијацију основа исте глаголске речи, као у дићи-дигнути, маћи-макнути и сл. [...] По томе би овај суфикс био бар делимично без резерве придружив фонду тематских елемената" (Симић 2005: 97). У морфемском смислу важно је указати да у зависности од функције има другачији морфемски статус. Када служи за перфективизацију тада је граматичка морфема, а када је факултативан као у стићи-стигнути и не утиче на гл. вид онда је творбена морфема, али свакако -ну- има двојаку морфемску вредност.

4. Након проведене анализе може се закључити да поред неспорно издвојених граматичких и творбених морфема постоје и гранични случајеви морфема које није лако одредити, попут истакнутих у анализи. Важно је да се 
ове морфеме јасно издвајају, али очито различити приступи и давање предности граматичком или творбеном (лексичком) нивоу дају и различита тумачења у литератури. За морфологију су подједнако важне и морфемска и морфолошка и творбена анализа и зато је опис и статус свих морфема јако битан. Неколико најтипичнијих проблема у морфемским анализама које су издвојене у раду показују колико је важно више пажње посветити морфематици, типовима морфема и употпунити и теоријски и конкретним анализама ово граматичко поље које нам је неопходно и у морфолошким и у творбеним анализама.

Расправљајући о морфолошкој анализи М. Николић је истакао циљ који је сагласан са циљем наше анализе, а то је да „циљ није толико да покажемо који је метод најпогоднији за морфолошку анализу [морфемску анализу C. Ђ.] колико да истакнемо колико је та анализа тежа и сложенија него што се то обично мисли" (Николић 2004: 11). Управо је циљ овог рада било скретање пажње на нека, али не и једина, спорна места у морфемским анализама која се морају више истраживати.

\section{ЛИТЕРАТУРА}

Бутакова 2012: Л.О. Бутакова, Морфемика и словообразование современного русского языка, Москва.

Гортан Премк 1996: Д. Гортан Премк, О несамосталним семантичким елементима у структури лексема, Јужнословенски филолог LII, 19-24.

Ђуровић/Спасојевић 2014: Сања Ђуровић, Марина Спасојевић, Још један поглед на видске парњаке у српском језику, Зборник Матице српске за филологију и лингвистику, LVII/1, 183-197.

Ђуровић 2017: Сања Ђуровић, Основни појмови морфематике српског језика, у: Зборник са Међународне научне конференције Словенска терминологија данас, гл. уредник Предраг Пипер, В. Јовановић, Српска академија наука и уметности и Институт за српски језик САНУ, 213-229.

Земска 2011: Е. А. Земская, Современный русский язык, Словообразование, Москва: Флинта, Издательство „Наука”.

Клајн 2002: Иван Клајн, Творба речи у савременом српском језику, први део: слагање и префиксација, Београд: Завод за уџбенике и наставна средства.

Клајн 2003: Иван Клајн, Творба речи у савременом српском језику, други део: суфиксација и конверзија, Београд: Завод за уџбенике и наставна средства. 
Кликовац 2002: Душка Кликовац, Граматика српског језика за основну школу, Београд: Српска школска књига.

Маројевић 2008: Радмило Маројевић, Српски језик данас, Београд, Бања Лука.

Маројевић 2012: Радмило Маројевић, Српски и словенски нулти суфикс, у: Зборник радова са 14. међународне конференције Комисије за творбу речи при МКС-у: Творба речи и њени ресурси у словенским језицима, 637-652.

Mrazović/Vukadinović 2009: Zora Vukadinović, Pavica Mrazović, Gramatika srpskog jezika za strance, Sremski Karlovci - Novi Sad: Izdavačka knjižarnica Zorana Stojanovića.

Николић 2004: Мирослав Николић, Морфонолошке алтернације и морфолошка анализа (на примерима из српског књижевног језика), Наш језик, 35/1-4, 6-12.

Пипер/Клајн 2013: Нормативна граматика српског језика, Нови Сад: Матица српска.

Симић 2005: Радоје Симић, Неке недоумице око морфологије глагола, Cpnски језик, X, 75-132.

Симић 2017: Радоје Симић, О глаголској префиксацији и префиксима, Нaw језик, XLVIII/3-4, 177-189.

Стакић 2002: Милан Стакић, Морфонологија и дериващија, Чланци и расправе, Београд: Филолошки факултет, Научно друштво за неговање и проучавање српског језика.

Станојчић/Поповић 2008: Живојин Станојчић, Љубомир Поповић, Граматика српскога језика за гимназије и средње школе. Београд: Завод за уџбенике и наставна средства.

Штасни 2017: Гордана Штасни, Морфемска и творбена анализа - проблемски приступ, Прилози настави српског језика и књижевности VI, 97-112. 


\section{PROBLEMS IN MORPHEME ANALYSIS IN SERBIAN LANGUAGE}

\section{Summary}

The subject of the paper are concrete examples of morphemic analysis of the word where problems arise in relation to determining the type of morphine and the classification of morphisms in terms of division into grammatical and forming morphemes. The intricacy and interconnection of morphemic and formative analysis often leads to twofold solutions, so the aim is to work out a proposal for a categorical and consistent morphism analysis, as well as a clear separation of morpheme, morphological and structural analysis as three basic morphology analyzes

Key words: morphology, morpheme, morpheme analysis, Serbian language

Sanja Ž. Đurovic 